\title{
Pulmonary hypertension in smoking mice over-expressing protease-activated
} receptor-2

\author{
G. De Cunto*, S. Cardini*, G. Cirino\#, P. Geppetti", G. Lungarella* and M. Lucattelli*
}

ABSTRACT: The mechanism(s) involved in the development of pulmonary hypertension (PH) in COPD is still the object of investigation. Cigarette smoke (CS) may lead to remodelling of intrapulmonary vessels and dynamic changes in vascular function, at least in some smokers. A role for proteases in $\mathrm{PH}$ has been recently put forward.

We investigated, in smoking mice, the role of protease-activated receptor (PAR)-2 in the pathogenesis of $\mathrm{PH}$ associated with emphysema.

We demonstrated that CS exposure can modulate PAR-2 expression in mouse lung. Acute CS exposure induces in wildtype (WT) and in transgenic mice over-expressing PAR-2 (FVB ${ }^{\text {PAR-2-TgN }}$ ) a similar degree of neutrophil influx in bronchoalveolar lavage fluids. After chronic CS exposure WT and FVB ${ }^{\text {PAR-2-TgN }}$ mice show emphysema, but only transgenic mice develop muscularisation of small intrapulmonary vessels that precedes the development of $\mathrm{PH}(\sim 45 \%$ increase) and right ventricular hypertrophy. Smoking in FVB ${ }^{\mathrm{PAR}-2-\mathrm{TgN}}$ mice results in an imbalance between vasoconstrictors (especially endothelin-1) and vasodilators (i.e. vascular endothelial growth factor, endothelial nitric oxide synthase and inducible nitric oxide synthase) and enhanced production of growth factors involved both in fibroblast-smooth muscle cell transaction (i.e. platelet-derived growth factor (PDGF) and transforming growth factor $\beta$ ) and vascular cell proliferation (PDGF).

PAR-2 signalling can influence the production and release of many factors, which may play a role in the development of $\mathrm{PH}$ in smokers.

KEYWORDS: Animal model of emphysema, cigarette smoke, pulmonary hypertension, right ventricular hypertrophy, vascular remodelling

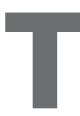
he most important risk factor for the development of chronic obstructive pulmonary disease (COPD) is cigarette smoke (CS) [1, 2]. Inhalation of cigarette smoke causes a chronic pulmonary inflammatory infiltrate of macrophages, neutrophils and CD8+ cells that persists long after smoking cessation [3]. In susceptible individuals, this ultimately leads to emphysema characterised by irreversible destruction and dilatation of the terminal airspaces of the lung, chronic disability due to respiratory failure and premature death. One established complication of COPD is the development of pulmonary hypertension (PH). Its presence is associated with shorter survival rates and worse clinical evolution [4].

Inflammation plays a pivotal role in the pathophysiology of COPD, as it is associated to an increase of oxidant burden and an abnormal secretion/activation of proteases, which may cause the proteolytic breakdown of interstitial matrix [5]. Some of these proteases, belonging to the serine group, may represent also signalling molecules that can activate cells by cleaving specific cell surface receptors called proteaseactivated receptors (PARs), a family of four Gprotein-coupled receptors.

After the discovery of the first PAR, the thrombin receptor PAR-1, three other receptors have been identified: PAR-2, PAR-3 and PAR-4 [6]. Among the four members so far identified, PAR-1 and PAR-2 are the most well characterised. PAR-1 is expressed on human platelets and vascular endothelial cells. PAR-2 is widely distributed, being found on vascular endothelial cells, fibroblasts,

\section{AFFILIATIONS}

*Dept of Physiopathology \& Experimental Medicine, University of Siena, Siena,

\#Dept of Experimental

Pharmacology, University of Naples Federico II, Naples, and

'Dept of Critical Care Medicine \& Surgery, University of Florence, Florence, Italy.

\section{CORRESPONDENCE}

M. Lucattelli

Dept of Physiopathology \&

Experimental Medicine

University of Siena

via Aldo Moro n.6

53100 Siena

Italy

E-mail: lucattelli@unisi.it

Received:

April 192010

Accepted after revision:

July 152010

First published online:

Aug 062010 
smooth muscle cells, bronchial endothelium, neutrophils, eosinophils, sensory neurons and cells of the gastro-intestinal tract $[7,8]$.

Recent studies demonstrate that PAR-2 is an integral component of the inflammatory process, and significantly, its expression by human endothelium is up-regulated by cytokines. The diffuse distribution of PAR-2 across cells from multiple systems suggests its potential role in both local and systemic inflammation [9]. Although PAR-2 activation is generally considered as proinflammatory, its role in the lung is controversial because there is evidence of both pro- and anti-inflammatory activities [8].

In the cardiovascular system, PAR-2 may play a role in vascular tone and blood pressure regulation as it is expressed on both vascular endothelium and smooth muscle cells [10]. Given its activation by coagulation enzymes (i.e. tissue factor VIIa/factor Xa complex), mast cell tryptase, epithelial proteases (e.g. trypsin) and enzymes released by inflammatory cells, PAR-2 could be a potential link between chronic lung inflammation and development of vascular changes in COPD $[8,11]$.

Chronic exposure of mice to cigarette smoke leads to lung inflammation and emphysema that, at least in part, mimic the lung changes observed in human COPD [3, 12-14]. In this study, we show that the over-expression of PAR-2 in transgenic mice $\left(\mathrm{FVB}^{\mathrm{PAR}-2-\mathrm{TgN}}\right)$, results in emphysema and a marked vascular remodelling of small intrapulmonary vessels in response to CS treatment. Vascular changes precede the development of $\mathrm{PH}$ and right ventricular hypertrophy (RVH). A series of alterations in gene expression of cytokines, growth factors and regulators of vascular tone characterises the increase of smooth muscle cells.

\section{MATERIALS AND METHODS}

An expanded materials and methods section is available in the online supplementary material.

All animal experiments were conducted in conformity with the "Guiding Principles for Research Involving Animals and Human Beings" and approved by the Local Ethics Committee of the University of Siena, Siena, Italy.

\section{Experimental animals}

Transgenic mice over-expressing PAR-2 (FVB $\left.{ }^{\mathrm{PAR}-2-\mathrm{TgN}}\right)$ were supplied by Roche Bioscience (Palo Alto, CA, USA). Generation of these mice has previously been described [15]. Wild type (WT) FVB/N mice were purchased from Charles River Italia (Calco, Italy).

\section{Experimental design}

The contribution of PAR-2 to CS-induced lung changes was examined by comparing the response obtained in $\mathrm{FVB}^{\mathrm{PAR}-2-\mathrm{TgN}}$ and WT mice. Four groups of mice were examined: $\mathrm{FVB}^{\mathrm{PAR}-2-\mathrm{TgN}}$ and WT mice exposed to either room air or to the smoke of 3 cigarettes day $^{-1}, 5$ days $\cdot$ week $^{-1}$ for $1,2,4$ and 7 months. In a preliminary experiment, we evaluated the potential role of PAR-2 in an acute smoke model of inflammation caused by the exposure of 5 cigarettes day $^{-1}$ for 3 consecutive days. The methodology for smoke exposure has previously been described in detail [16].

\section{Morphology and morphometry}

At 2, 4 and 7 months after chronic exposure to room air or CS, 12 animals of each group were sacrificed under anaesthesia with sodium pentobarbital and the lungs removed for morphological and morphometric assessment of emphysema. At 4 and 7 months after CS exposure measurements of right ventricular systolic pressure $\left(P_{\mathrm{rv}, \mathrm{s}}\right)$ and assessment of $\mathrm{RVH}$ was performed.

\section{Immunohistochemical analysis}

The degree of muscularisation of small and medium vessels was determined after immunohistochemical staining for $\alpha$ smooth muscle actin ( $\alpha$-SMA).

Tissue sections from mice exposed to room air or CS for 2, 4 and 7 months were also stained for transforming growth factor (TGF)- $\beta$, platelet-derived growth factor (PDGF)- $\beta$, vascular endothelial growth factor (VEGF)-A, endothelin (ET)-1, endothelial nitric oxide synthase (eNOS), inducible nitric oxide synthase (iNOS) and hypoxia-inducible factor 1 (HIF-1)- $\alpha$ protein. Some tissue sections from mice of both genotypes were also stained for PAR-2 in order to see whether CS exposure modifies the expression of the receptor.

\section{Protein and RNA analysis}

At 1 month after exposure to room air or CS, lungs from eight mice for each group were analysed by real-time RT-PCR for $\alpha$-SMA, Tgfb1, Pdgfb, ET-1, Vegf-A, eNOS, iNOS, HIF-1- $\alpha$ and $18 \mathrm{~S}$ rRNA.

At 4 and 7 months after exposure to room air or CS, lungs from eight mice for each group were analysed by western blots for eNOS, phospho-eNOS and VEGF.

Plasma ET-1 assay was carried out on additional eight FVB $^{\text {PAR-2-TgN }}$ and eight WT mice exposed to room air or chronic CS for 4 and 7 months.

\section{Proliferation and apoptosis indices}

At 1 month after CS exposure, SM cells of small lung vessels undergoing apoptosis or proliferation were evaluated by terminal deoxy-nucleotidyltransferase-mediated dUTP nickend labelling (TUNEL) assay or by immunostaining with proliferating cell nuclear antigen (PCNA), respectively.

The above-mentioned methods are provided in detail in the online supplementary material.

\section{Statistical analysis}

Data are presented as mean $\pm \mathrm{SD}$. The significance of the differences was calculated using one-way analysis of variance. A p-value $<0.05$ was considered significant.

\section{RESULTS}

\section{PAR-2 hyperexpression in FVB mice did not modify the bronchoalveolar lavage fluid cell profile in response to acute cigarette smoke}

In preliminary experiments, we evaluated the potential role of PAR-2 in an acute smoke model of inflammation caused by CS exposure ( 5 cigarettes $\cdot \mathrm{day}^{-1}$ for 3 consecutive days). CS exposure induced a significant increase of neutrophils in smoking animals of both genotypes; however, we did not observe 
significant differences in bronchoalveolar lavage fluid (BALF) cell counts between smoking WT and FVB ${ }^{\text {PAR-2-TgN }}$ mice (table 1 in the online supplementary material).

\section{Expression of PAR-2 in smoking mice}

An increased expression of PAR-2 was found in lung of WT FVB mice starting from 1 month after CS exposure (fig. 1 in the online supplementary material).

\section{Cigarette smoke causes lung emphysema in WT and FVB $^{\text {PAR-2-TgN }}$ mice}

The lungs of FVB ${ }^{\mathrm{PAR}-2-\mathrm{TgN}}$ and WT mice exposed to air showed a well-fixed normal parenchyma with normal airways (figs. 1a and c). 7 months after exposure to CS the lungs of both, FVB $^{\text {PAR-2-TgN }}$ and WT mice showed similar degree of emphysema as assessed by morphology (figs. $1 \mathrm{~b}$ and $\mathrm{d}$ ) and morphometry (table 1).

\section{Cigarette smoke causes vascular remodelling, pulmonary hypertension and right ventricular hypertrophy only in FVB $^{\text {PAR-2-TgN }}$ mice}

$\mathrm{FVB}^{\mathrm{PAR}-2-\mathrm{TgN}}$ mice developed a marked lung vascular remodelling after CS exposure. The vascular changes preceded the development of $\mathrm{PH}$ and $\mathrm{RVH}$.

The values of $P_{\mathrm{rv}, \mathrm{s}}$ of FVB ${ }^{\mathrm{PAR}-2-\mathrm{TgN}}$ and WT mice obtained at 4 and 7 months after CS and air exposure are shown in table 1. Prv,s was significantly increased at 7 months in smoking FVB $^{\text {PAR-2-TgN }}$ mice $(+45 \%)$ with respect to the control mice. No changes in Prv,s were observed between smoking and air-control FVB ${ }^{\mathrm{PAR}-2-\mathrm{TgN}}$ mice at 4 months and smoking and aircontrol WT mice at 4 and 7 months after CS.

The presence of $\mathrm{PH}$ in transgenic mice is accompanied by $\mathrm{RVH}$ as demonstrated by the significant increase in the ratio of RV/ $\mathrm{LV}+\mathrm{S}$ weight at 7 months after CS exposure (table 1). RV/ $\mathrm{LV}+\mathrm{S}$ weight did not differ between smoking and air-exposed
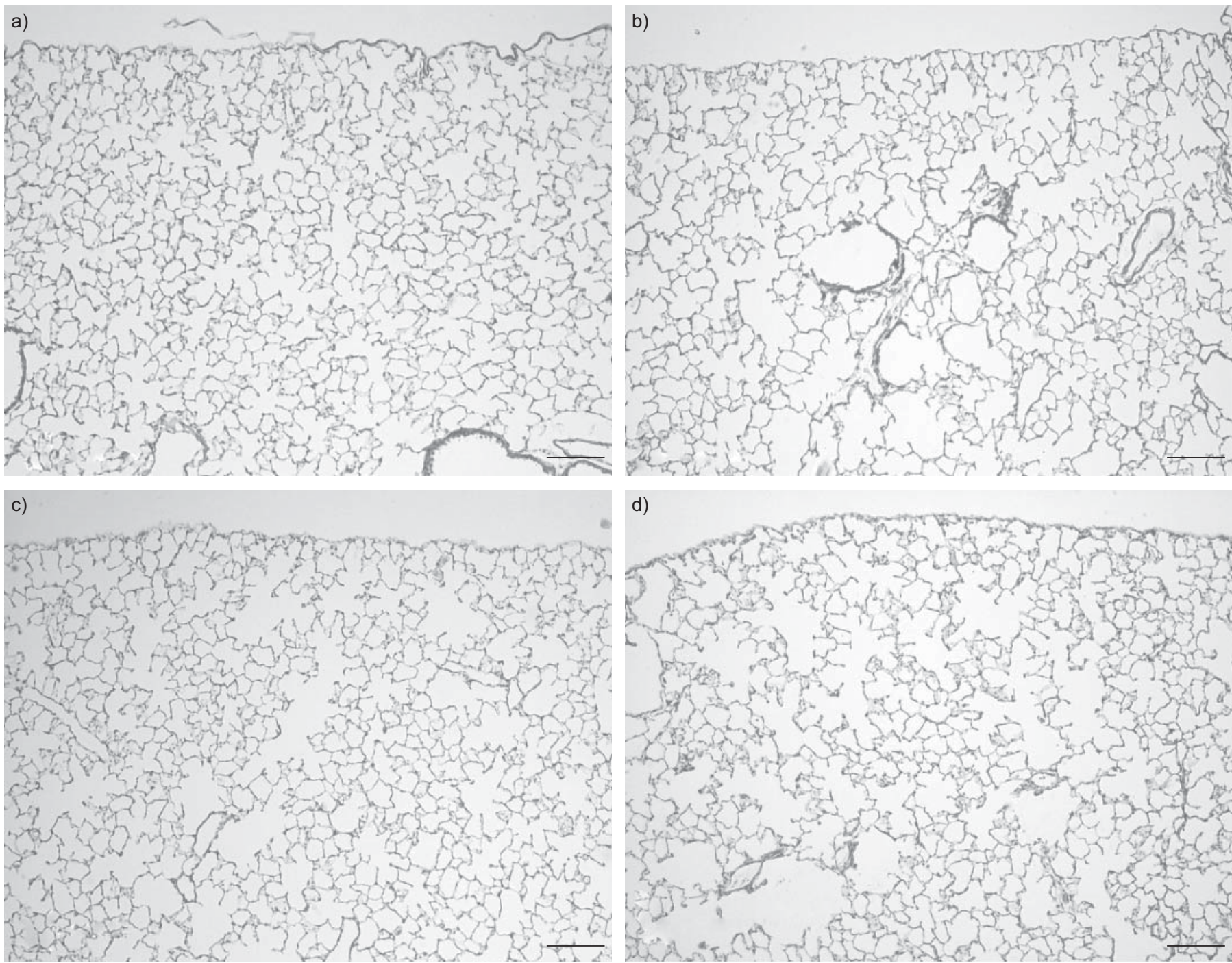

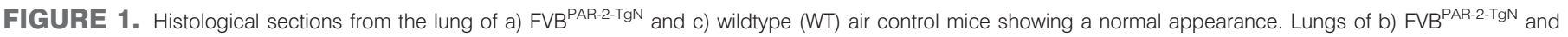
d) WT after 7 months of cigarette smoke exposure show focal areas of emphysema. Haematoxylin and eosin stain. Scale bars: $120 \mu \mathrm{m}$. 


\begin{tabular}{|c|c|c|c|c|c|c|c|c|}
\hline TABLE 1 & $\begin{array}{l}\text { orphometry, } \\
-2-\operatorname{TgN} \text { mice a }\end{array}$ & $\begin{array}{l}\text { ght ventricul } \\
4 \text { and } 7 \text { mor }\end{array}$ & $\begin{array}{l}\text { systolic pr } \\
\text { s after chrc }\end{array}$ & $\begin{array}{l}\text { ure }(P r v, s) \\
\text { exposure }\end{array}$ & $\begin{array}{l}\text { Fulton's i } \\
\text { ither roor }\end{array}$ & $\begin{array}{l}\text { determin } \\
\text { or cigare }\end{array}$ & $\begin{array}{l}\text { in wildtype } \\
\text { smoke }\end{array}$ & NT) and \\
\hline \multirow[t]{2}{*}{ Group } & \multicolumn{2}{|c|}{$\operatorname{Lm} \mu \mathrm{m}$} & \multicolumn{2}{|c|}{ ISA $\mathrm{cm}^{2}$} & \multicolumn{2}{|c|}{ Prv,s mmHg } & \multicolumn{2}{|c|}{ RV/LV+septum } \\
\hline & 4 months & 7 months & 4 months & 7 months & 4 months & 7 months & 4 months & 7 months \\
\hline \multicolumn{9}{|l|}{ Room air } \\
\hline FVB WT & $34.15 \pm 1.06$ & $36.48 \pm 1.17$ & $1307 \pm 53$ & $1279 \pm 49$ & $26.4 \pm 1.3$ & $26.7 \pm 1.7$ & $0.201 \pm 0.017$ & $0.197 \pm 0.014$ \\
\hline FVB ${ }^{\text {PAR-2-TgN }}$ & $34.19 \pm 0.81$ & $35.43 \pm 0.84$ & $1329 \pm 61$ & $1318 \pm 58$ & $26.1 \pm 0.9$ & $26.2 \pm 0.7$ & $0.230 \pm 0.014$ & $0.232 \pm 0.012$ \\
\hline \multicolumn{9}{|l|}{ Smoke } \\
\hline FVB WT & $39.23 \pm 1.60^{*}$ & $40.23 \pm 0.79^{*}$ & $1174 \pm 64^{\star}$ & $1096 \pm 37^{*}$ & $26.7 \pm 1.9$ & $26.9 \pm 1.9$ & $0.210 \pm 0.016$ & $0.213 \pm 0.017$ \\
\hline FVB $^{\text {PAR-2-TgN }}$ & $38.71 \pm 1.40^{*}$ & $40.22 \pm 1.58^{*}$ & $1098 \pm 127^{\star}$ & $1069 \pm 84^{\star}$ & $27.3 \pm 0.9$ & $38.3 \pm 0.6^{*}$ & $0.237 \pm 0.014$ & $0.318 \pm 0.031$ * \\
\hline
\end{tabular}

Data are presented as mean \pm SD. Lm: mean linear intercept; ISA: internal surface area of the lungs; RV: right ventricle; LV: left ventricle. *: $p<0.05$ versus the group exposed to air.

$\mathrm{FVB}^{\mathrm{PAR}-2-\mathrm{TgN}}$ mice at 4 months as well as between smoking and air-control WT mice at 4 and 7 months.

A significant vascular remodelling, characterised by an increase of smooth muscle cells in small intrapulmonary vessels precedes and accompanies the development of $\mathrm{RVH}$ and $\mathrm{PH}$ in smoking $\mathrm{FVB}^{\mathrm{PAR}-2-\mathrm{TgN}}$ mice.

Plexiform or angiomatoid lesions, which usually occur in idiopathic $\mathrm{PH}$ in man, were not observed in smoking $\mathrm{FVB}^{\mathrm{PAR}-2-}$ $\mathrm{TgN}$ mice under our experimental conditions.

Smoking FVB ${ }^{\text {PAR-2-TgN }}$ mice exhibited significant increase in muscularisation of small pulmonary vessels over air-control mice (fig. 2). At 2 months, in air-exposed controls of both strains, $<15 \%$ of small vessels were muscularised $(12 \pm 2$ in WT versus $11 \pm 3$ in $\mathrm{FVB}^{\mathrm{PAR}-2-\mathrm{TgN}}$ mice, $\mathrm{n}=12$ ) (fig. $2 \mathrm{a}$ ). Similar values were obtained in air-exposed groups of both genotypes at 4 and 7 months. At 2, 4, and 7 months after CS exposure, $14 \pm 4 \%, 15 \pm 3 \%$ and $15 \pm 4 \%$ small pulmonary vessels of WT mice, and $49 \pm 5 \%, 51 \pm 7 \%$ and $52 \pm 5 \%$ of small vessels of $\mathrm{FVB}^{\text {PAR-2-TgN }}$ mice, respectively, were muscularised $(\mathrm{p}<0.01$ for the differences of muscularised vessels between genotypes).

As shown in fig. $2 b$, the differences in muscularisation of small pulmonary vessels between genotypes at 7 months can be accounted for by an increase in the percentage of both partially and fully muscularised vessels. In contrast, most medium vessels with a diameter of $81-150 \mu \mathrm{m}$ were fully muscularised $(87 \pm 5 \%$ in WT versus $90 \pm 6 \%$ in $\mathrm{FVB}^{\mathrm{PAR}-2-\mathrm{TgN}}$ mice; $\mathrm{p}=\mathrm{NS}$ ). No increase in the percentage of muscularised medium vessels was observed in both mouse strains after CS exposure (data not shown).

At 7 months, small pulmonary vessels of smoking FVB $^{\text {PAR-2- }}$ ${ }^{\mathrm{TgN}}$ mice also showed thickening of the fully muscularised SM wall as evidenced by the increase in percent vessel wall thickness (\%VWT) compared with that of their air-exposed controls $(29.1 \pm 4.0$ versus $19.2 \pm 3.1 ; p>0.05)$. No significant increase in \%VWT was found in the smoking WT mice in respect to their respective air-exposed controls $(19.0 \pm 2.9$ versus $18.1 \pm 2.1)$

Figure 2c and d illustrates representative immunohistochemistry images for $\alpha$-SMA in pulmonary vessels from both genotypes 7 months after CS exposure.

\section{Vascular remodelling in smoking FVB ${ }^{P A R-2-T g N}$ mice is not linked to HIF-1 hyper-expression}

It has recently been reported that hypoxia-inducible factor 1 (HIF-1)- $\alpha$ can promote proliferative response of vascular smooth muscle cells $[17,18]$. In our experimental condition, we detected appreciable amount of this factor only at 7 months after CS exposure, when vascular remodelling was already evident (fig. 3). A positive reaction for this factor was evident on small (arrowheads) and medium (arrows) pulmonary vessels from both genotypes.

\section{The combination of chronic CS exposure with over-expression of PAR-2 gene results in a vasoconstrictors/vasodilators imbalance}

A series of bioactive substances such as TGF- $\beta$, PDGF- $\beta$, ET-1, VEGF, eNOS and iNOS were investigated at various time points in the two mouse genotypes.

A strong positive immunohistochemical reaction for TGF- $\beta$ was found in vessels of $\mathrm{FVB}^{\text {PAR-2-TgN }}$ mice as early as at 2 months after CS, with a maximal staining at 4 months (fig. $4 \mathrm{~b}$, arrow). At the same times, no immuno-reaction for this cytokine was seen on small pulmonary vessels of smoking WT mice (fig. 4d, arrow). Additionally, no reaction was found in lung vessels from the air-exposed groups of the two genotypes (fig. $4 a$ and c). Immunohistochemical grading for TGF- $\beta$ is reported in figure $4 \mathrm{e}$.

With regard to PDGF- $\beta$, a progressive increased signal was seen in pulmonary vessels of smoking FVB ${ }^{\text {PAR-2-TgN }}$ mice starting from month 4 , with a maximal reaction at month 7 (fig. $4 \mathrm{~g}$, arrows). A positive signal for this cytokine was currently found in bronchial and bronchiolar epithelium from air- and smoke exposed mice of both genotypes, but not in lung vessels from air- and smoke-exposed WT (fig. 4 h and i, arrow) and air-exposed transgenic mice (fig. 4f, arrow). The immunohistochemical-based grading analysis for this mediator is reported in figure $4 \mathbf{j}$.

Lung vascular changes in smoking FVB ${ }^{\text {PAR-2-TgN }}$ mice were also characterised by an enhanced expression of the vasoconstrictor ET-1 in endothelial and smooth muscle cells of middle and small pulmonary vessels as well as of alveolar capillaries. This reaction was clearly evident at all times after CS exposure (fig. 5b-e). 

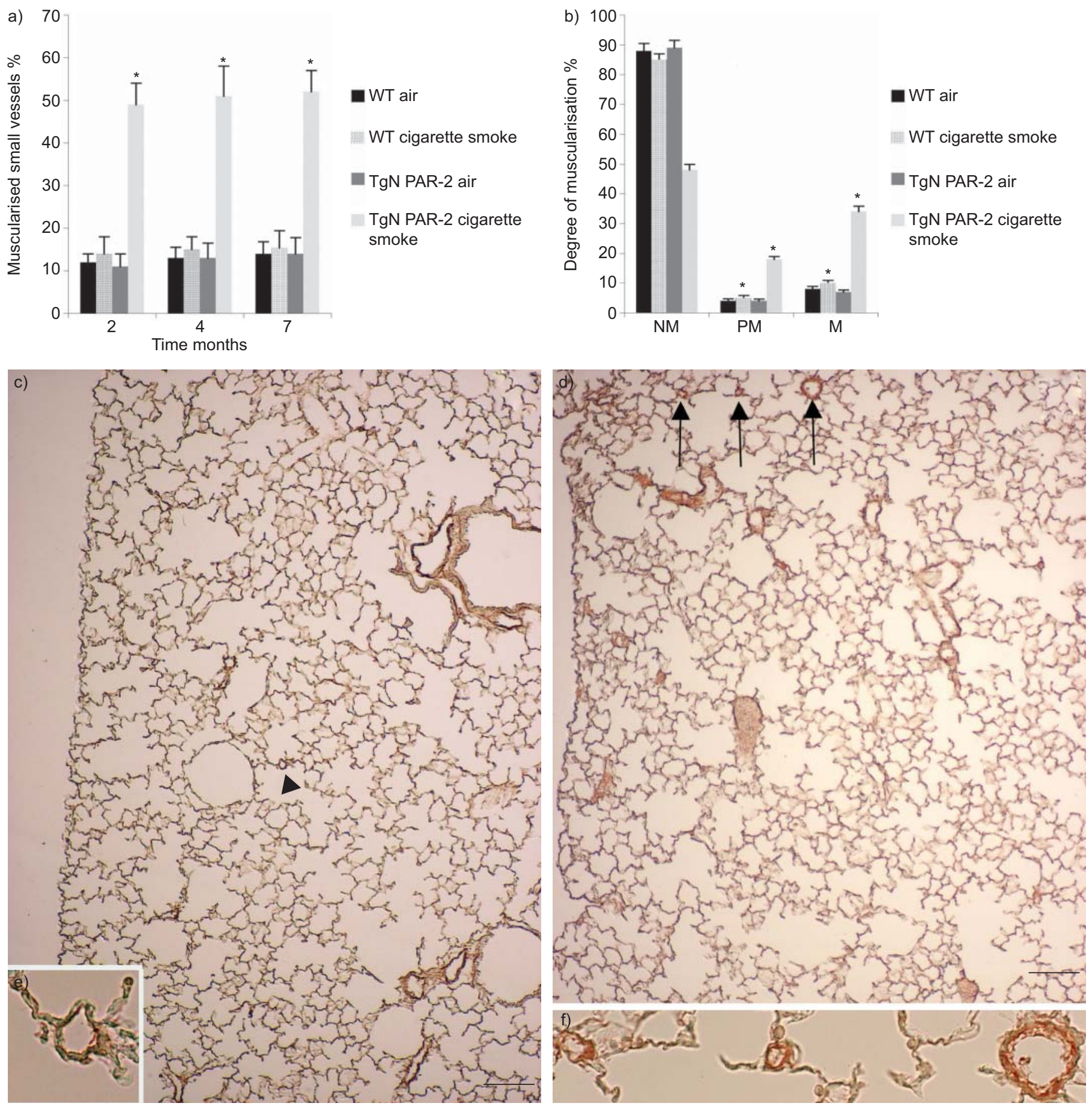

FIGURE 2. Muscularisation of small ( $\leqslant 80 \mu \mathrm{m}$ ) vessels in wildtype (WT) and FVB $\mathrm{BAR}^{\text {PA-TgN }}$ mice after exposure to cigarette smoke (CS) or air. a) Percentage of small lung vessels showing any degree of muscularisation at indicated time points. b) Percentage of nonmuscular (NM), partially muscular (PM) and fully muscular (M) small vessels at 7 months after cigarette smoke exposure. *: $p \leqslant 0.01$ versus air control groups. Representative immunohistochemical staining for $\alpha$-smooth muscle actin (SMA) on lung parenchyma of c) WT and d) FVB PAR-2-TgN mice at 7 months after CS exposure. Immunostaining with anti- $\alpha$-SMA antibodies shows excessive thickening of $\alpha$-SMA-positive layers in small intrapulmonary vessels of FVB ${ }^{\text {PAR-2-TgN }}$ mice (inset as f). e) A small lung vessel from WT mouse at 7 months after CS exposure is reported for comparison. Scale Bars: $150 \mu$ m.

Only a faint reaction for ET-1 was appreciated on vessels of lung sections from air control FVB ${ }^{\mathrm{PAR}-2-\mathrm{TgN}}$ (fig. 5a) and from WT mice at 7 months after CS (fig. 5f). The immunohistochemicalbased grading analysis for ET- 1 at the various time points is shown in fig. $5 \mathrm{~g}$.
Of interest, the plasma ET-1 levels were significantly increased in smoking transgenic mice at 4 and 7 months $(+158.2 \%$ and $291.2 \%$, respectively) as compared with air exposed mice $\left(181 \mathrm{fmol} \cdot \mathrm{mL}^{-1}\right)$. Additionally, the mean plasma ET-1 levels were also found to be significantly increased in WT mice at the 

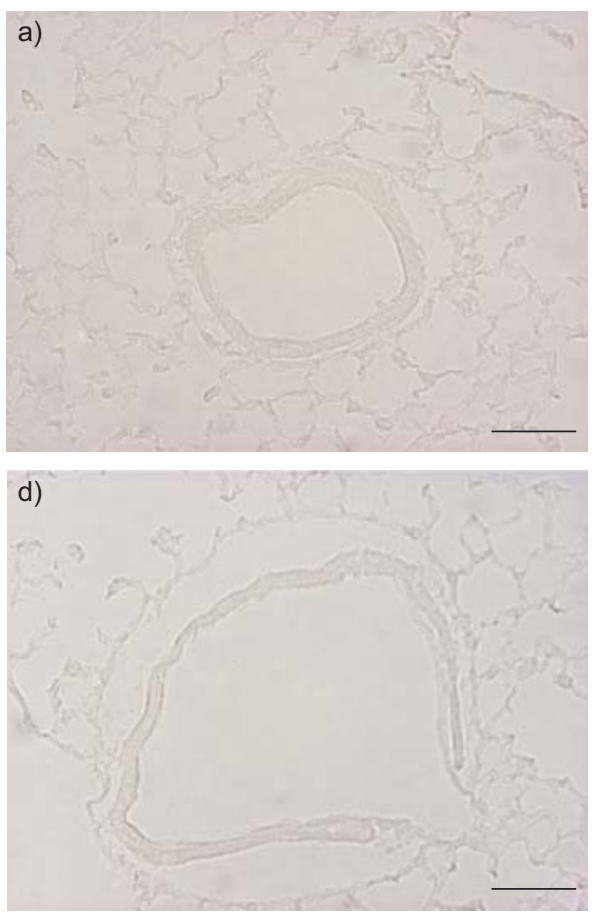
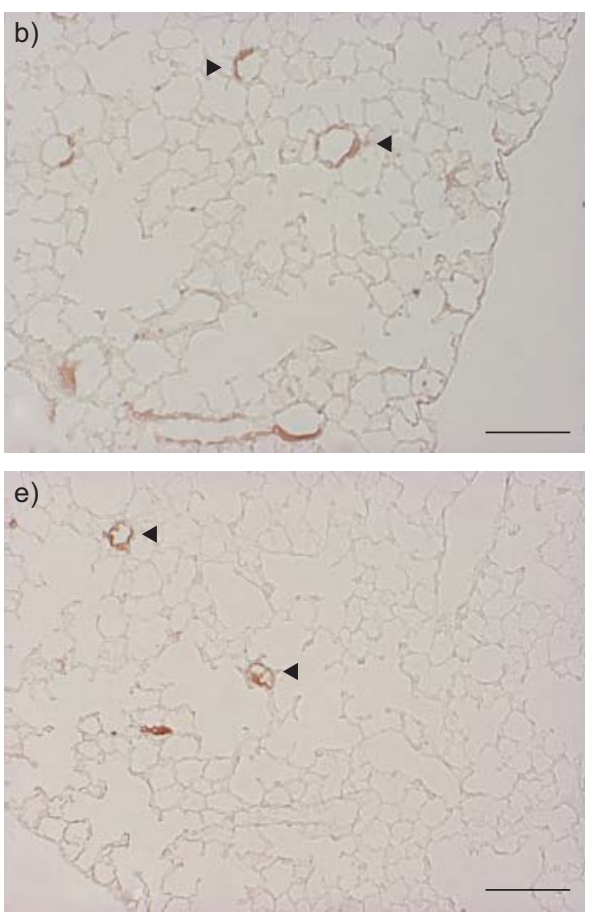
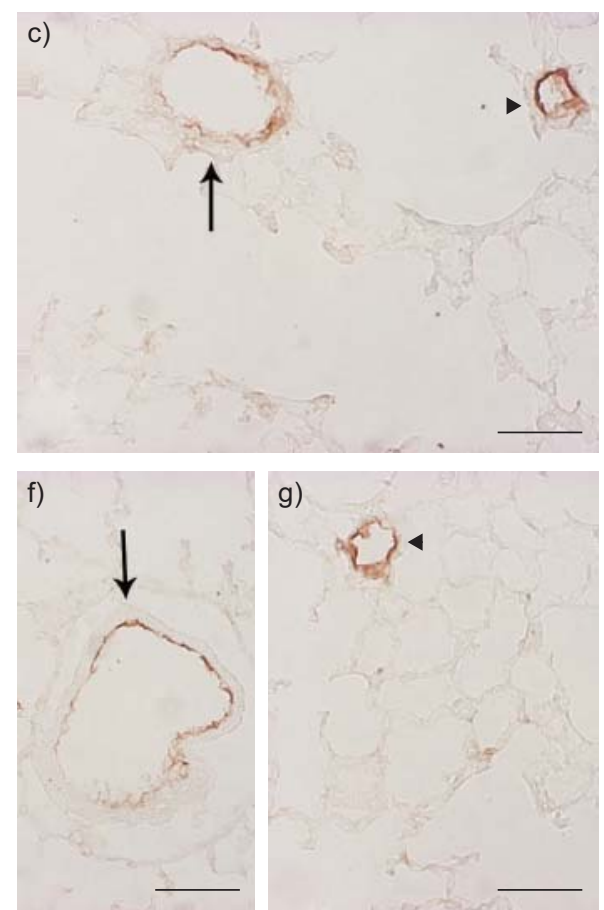

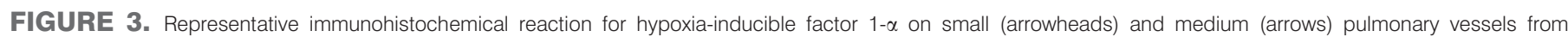

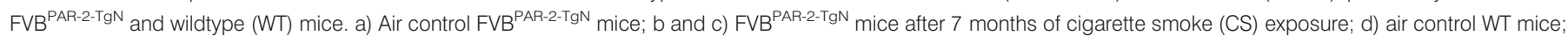
e-g) WT mice after 7 months of CS exposure. Scale bars: $150 \mu \mathrm{m}$ for b and e; and $75 \mu \mathrm{m}$ for a, c, d, f and g.

same time points $(+45.6 \%$ and $+61.5 \%$, respectively) with respect to their air-controls $\left(206 \mathrm{fmol} \cdot \mathrm{mL}^{-1}\right)$, but at lower extent than those found in FVB ${ }^{\mathrm{PAR}-2-\mathrm{TgN}}$ mice.

In the lungs of air-control transgenic mice, only a minimal reaction for VEGF was appreciable in the middle and small vessels, as well as in lung epithelial cells (fig. 6a). An increased VEGF expression could be observed in smoking transgenic mice only at 4 months after CS exposure (fig. 6b). A more evident VEGF signal was seen in lungs of air exposed WT mice as compared to those of transgenic mice (fig. 6c). Unlike transgenic mice, no changes of VEGF expression were found in WT animals at the different time points after CS exposure (fig. 6d). The immunohistochemical-based grading analysis for this cytokine is reported in figure $6 \mathrm{e}$.

An increased VEGF expression (kDA 48) was also observed at 4 months in whole lung tissue from smoking transgenic mice after Western blotting (WB) analysis (fig. 6f).

A positive immunostaining for eNOS was seen on lung vessels of air-exposed (fig. $6 \mathrm{~g}$ and i) and smoke-exposed transgenic and WT mice at 2 and 4 months. This reaction just returned to the control levels in smoking animals of both genotypes at 7 months (fig. $6 \mathrm{~h}$ and j). Of interest, only in FVB PAR-2-TgN mice a positive staining for eNOS was evident in some small vessels at this time point (fig. 6h). In fig. $6 \mathrm{k}$ data on the immunohistochemical-based grading analysis for eNOS at the various time points is shown.

Using antibodies specifically directed against the Ser ${ }^{1177}$ phosphorylation site of the eNOS (the preferential site of activation of eNOS by VEGF) [19], we analysed the expression of active eNOS relative to whole eNOS (140 kDA). A basal phosphorylation was detectable by WB in lung tissues from both air exposed WT and transgenic mice (fig. 61). An enhancement in phosphorylation of eNOS at Ser ${ }^{1177}$ was observed in smoking FVB ${ }^{\text {PAR-2-TgN }}$ mice after 4 months, with a significant decrease of the active form at 7 months. On the contrary, at 7 months after CS exposure the protein band corresponding to phosphorylated eNOS appeared increased in WT when the band of whole eNOS was significantly decreased. Of interest, a chronological parallel between VEGF and phosphorylation of eNOS occurs in FVB ${ }^{\text {PAR-2-TgN }}$ mice.

No detectable immuno-reaction was found for the vasodilator iNOS at any time points under our experimental conditions (data not shown).

These findings altogether suggest that an imbalance between vasoconstrictors/vasodilators occurs in the vascular bed of CS exposed FVB ${ }^{\text {PAR-2-TgN }}$ mice.

\section{The increase in muscularisation of lung vessels in smoking FVB ${ }^{P A R-2-T g N}$ mice is due to an increased proliferation of SM cells}

To investigate whether the increase in muscularisation of lung vessels was associated with an increase in proliferation or/and a decrease in apoptosis of SM cells, proliferation and apoptosis indexes were examined at 1 month after CS exposure. This time was chosen because muscularisation of small pulmonary arteries was readily evident at 2 months and thus the processes of proliferation or apoptosis might have already occurred in this time point. 

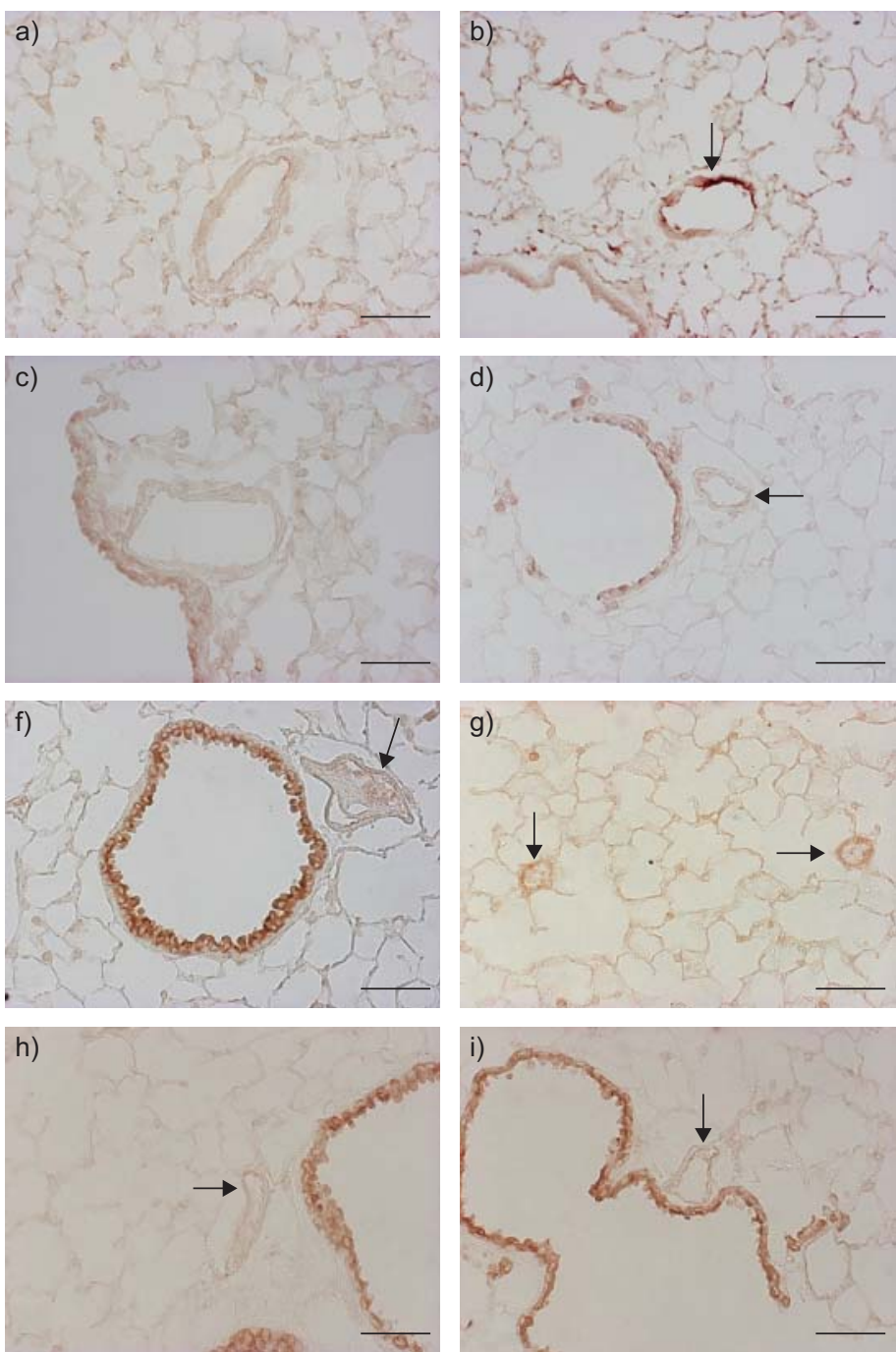
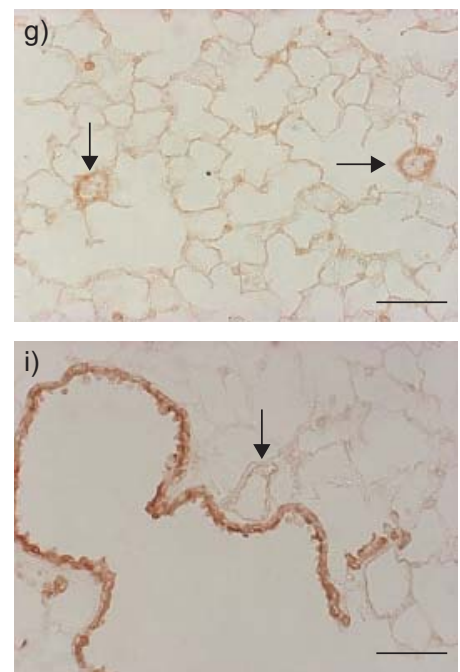
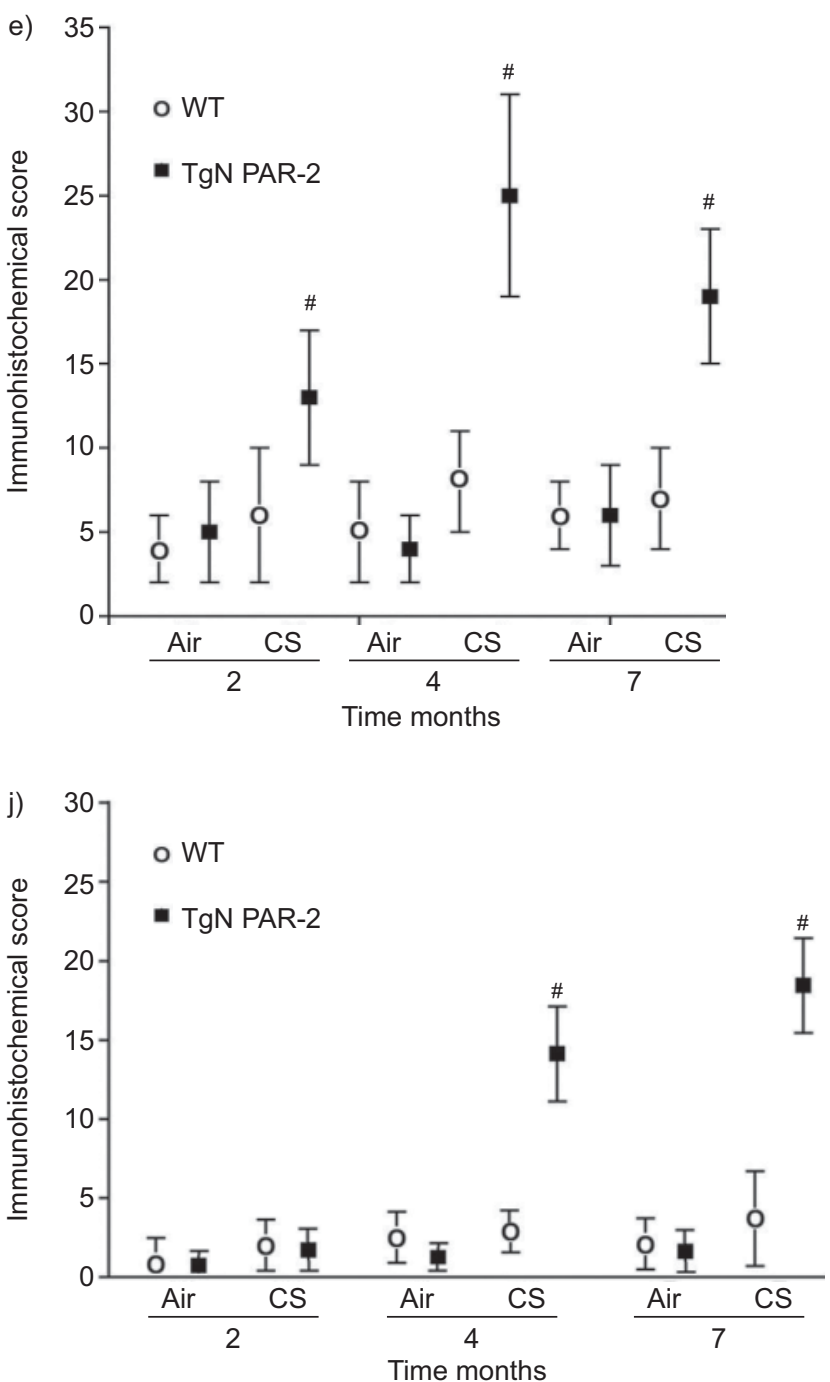

FIGURE 4. Photographic panel illustrating immunohistochemical staining for $a-d)$ transforming growth factor (TGF)- $\beta$ and f-i) platelet-derived growth factor (PDGF)- $\beta$ on lung sections of FVB ${ }^{\text {PAR-2-TgN }}$ and wildtype (WT) mice. a) TGF- $\beta$ staining in air control FVB ${ }^{\text {PAR-2-TgN }}$ mouse; b) FVB ${ }^{\text {PAR-2-TgN }}$ mice after 4 months of cigarette smoke (CS) exposure; c) air control WT mice; and d) WT mice after 4 months of CS exposure. Arrows point to small pulmonary vessels. f) PDGF- $\beta$ staining in air control FVB ${ }^{\text {PAR-2-TgN }}$ mouse; g) FVB PAR-2-TgN mice after 7 months of CS exposure; h) air control WT mice; and i) WT mice after 7 months of CS exposure. Arrows point to small pulmonary vessels. Scale bars: $75 \mu \mathrm{m}$. Immunohistochemical-based grading analysis for e) TGF- $\beta$ and j) PDGF- $\beta$, was carried out on small arteries of lungs from air- or smoke-exposed mice for each experimental group at 2, 4 and 7 months of treatment. Data are presented as mean \pm SD. ${ }^{*}: p \leqslant 0.05$ compared with air-control small vessels of the same genotype at the same time point.

We found only a very small number of TUNEL-positive SM cells in the lung sections of air- and CS-exposed WT or PAR-2 transgenic mice, and no significant difference in TUNEL staining between the two genotypes at 1 month after CS (data not shown). Alternatively, the number of PCNA-positive SM cells in small distal arteries of smoking FVB ${ }^{\text {PAR-2-TgN }}$ group appeared to be greater than that of smoking WT mice (fig. 7a-c). No differences among air-control WT, air-control PAR-2 transgenic and smoking WT mice were found in the ratio of PCNA-positive nuclei to total nuclei of SM cells (data not shown).

The increased proliferation of SM cells in small distal arteries of the lungs of smoking FVB ${ }^{\text {PAR-2-TgN }}$ was accompanied by a significant up-regulation of mRNA for $\alpha$-SMA, whereas no change in mRNA expression for $\alpha$-SMA was seen in WT mice at the same time point (fig. 7f). Of interest, a strong reaction for
PAR-2 was found on muscularised small vessels from WT and smoking $\mathrm{FVB}^{\mathrm{PAR}-2-\mathrm{TgN}}$ mice at 7 months after CS exposure (fig. 7d and e).

The combination of CS with the hyper-expression of PAR-2 gene resulted also in up-regulation of mRNAs for TGF- $\beta$, PDGF- $\beta$, ET-1, eNOS, and VEGF (fig. 7f). Of interest, only a slight increase of mRNAs for some of these mediators was observed at RT-PCR analysis in smoking WT mice.

\section{DISCUSSION}

We report here that PAR-2 over-expression in mice did not modify the influx of inflammatory cells in BALF after acute exposure to CS. In addition, $\mathrm{FVB}^{\mathrm{PAR}-2-\mathrm{TgN}}$ mice developed after chronic smoke exposure pulmonary emphysema at the same extent of that of WT mice. 

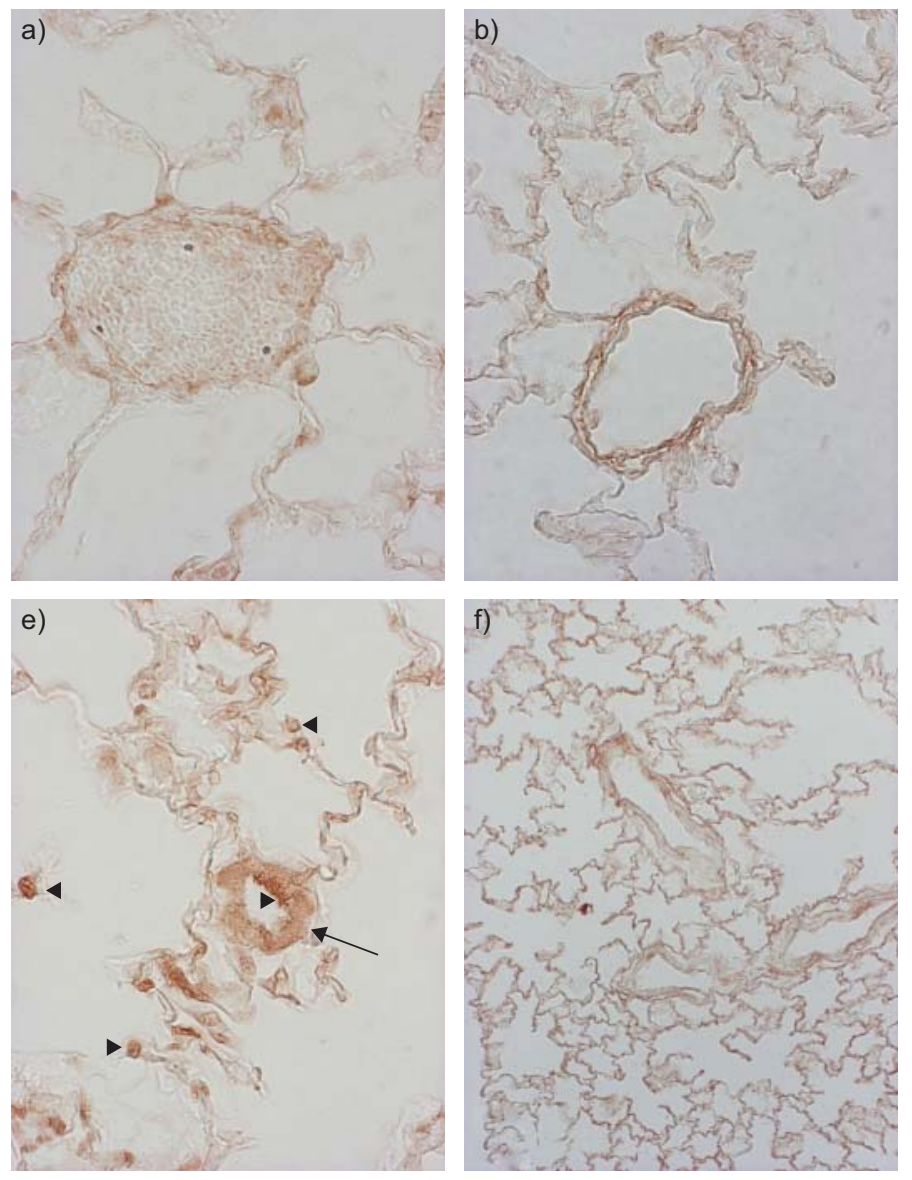
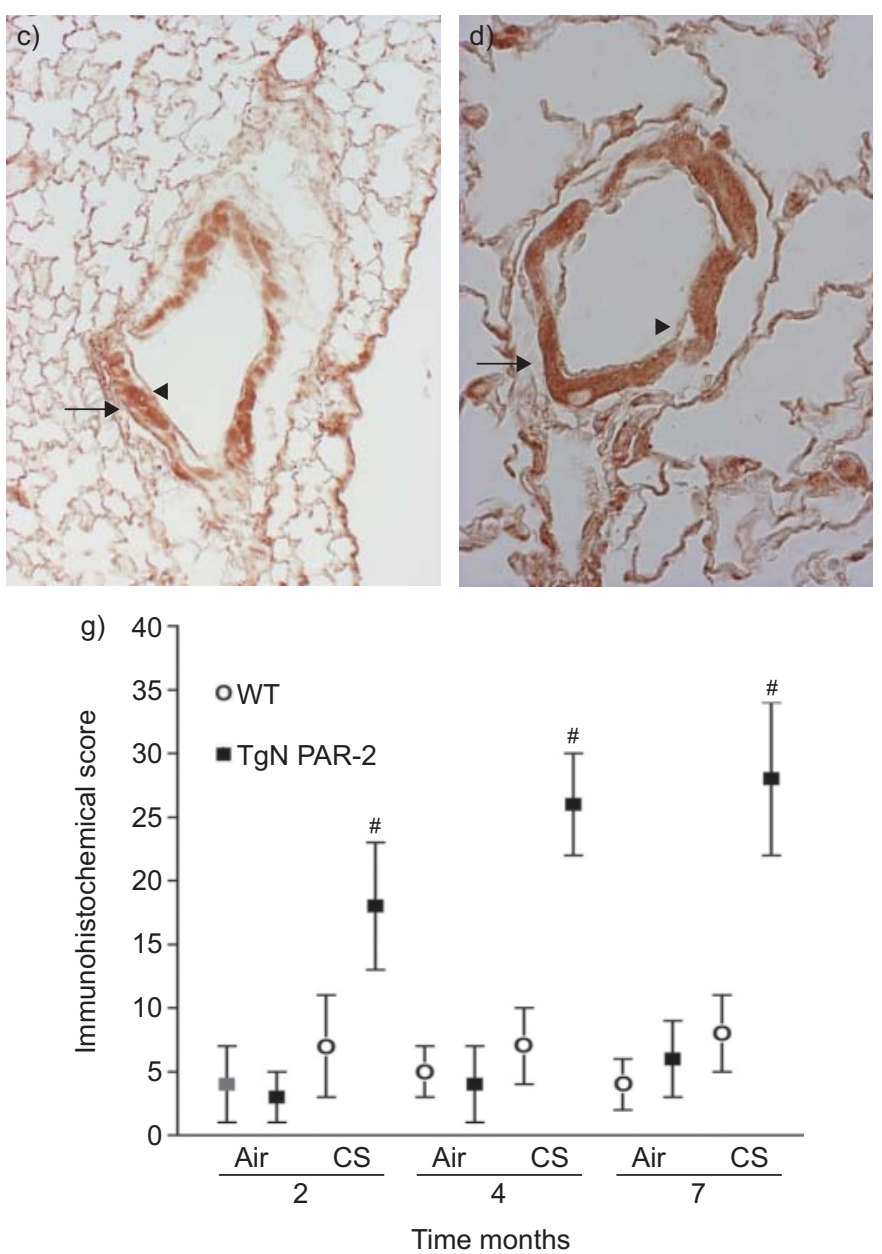

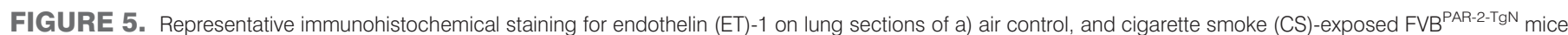

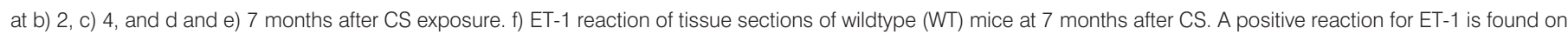

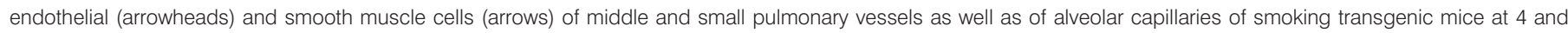

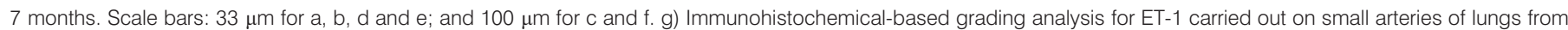

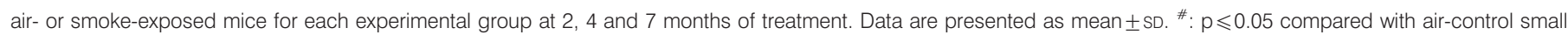
vessels of the same genotype at the same time point.

However, pulmonary emphysema in mice over-expressing PAR-2 was accompanied by the development of $\mathrm{PH}, \mathrm{RVH}$ and vascular changes reminiscent of human PH in COPD [20, 21]. It also appears that PAR-2 hyper-expression by itself was not sufficient to cause $\mathrm{PH}$, but in combination with CS exposure it could promote the development of $\mathrm{PH}$.

Unlike WT mice, FVB ${ }^{\text {PAR-2-TgN }}$ mice showed, at 7 months after CS exposure, areas of significant emphysema associated with $\sim 45 \%$ increase in mean $P r v, s$, and a marked vascular remodelling of small pulmonary vessels. Vascular changes and RVH were not observed in WT mice exposed to CS, which developed a similar degree of emphysematous lesions.

These data altogether suggest that alveolar destruction by itself is not sufficient to cause smoking-induced cor pulmonale in FVB smoking mice.

In response to $\mathrm{CS}$, the hyper-expression of the PAR-2 in FVB mice resulted in a series of alterations in gene expression of vasoconstrictors, vasodilators and growth factors involved in the process of vascular remodelling [22-26]. The increased muscularisation of small vessels was preceded by enhanced production of growth factors involved in fibroblast-SMC transaction (PDGF and TGF- $\beta$ ) $[27,28]$ and vascular cell proliferation (PDGF) [29, 30], and by an imbalance between vasoconstrictors (especially ET-1) and vasodilators (i.e. VEGF, eNOS and iNOS).

These events may be originated by different cell signalling pathways that follow to PAR-2 activation. In particular, activation of mitogen-activated protein kinase, protein-tyrosine phosphatase SHP2 and tyrosine kinase pathways could contribute to PAR-2-mediated cytokine production and mitogenic signalling [31].

Of interest, the imbalance between vasoconstrictors and vasodilators in transgenic mice appears to be due to a constant up-regulation of ET-1 not counteracted by a parallel increase of some important vasodilators (such as eNOS, iNOS and VEGF-A). These changes were not accompanied by an increased expression and accumulation of HIF- $1 \alpha$, an important mediator 

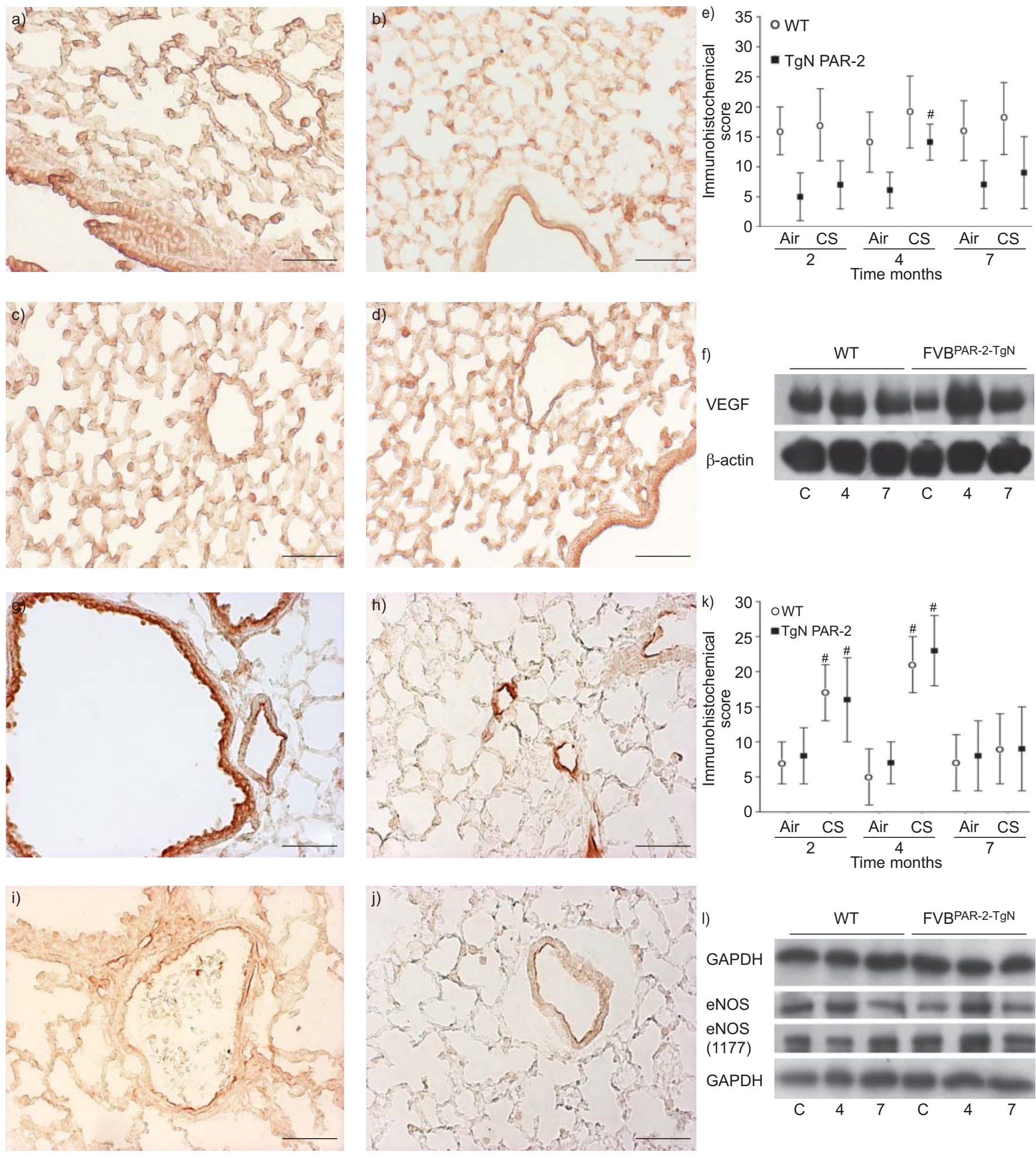

FIGURE 6. Representative immunohistochemical reactions for a-d) vascular endothelial growth factor (VEGF) and g-j) endothelial nitric oxide synthase (eNOS) on lung sections of FVB ${ }^{\text {PAR-2-TgN }}$ and wildtype (WT) mice. a) VEGF staining in air control FVB ${ }^{\text {PAR-2-TgN }}$ mice; b) FVB ${ }^{\text {PAR-2-TgN }}$ mice after 4 months of cigarette smoke (CS) exposure; c) air control WT mice; and d) WT mice after 4 months of CS exposure. g) eNOS immunolocalisation in air control FVB ${ }^{\text {PAR-2-TgN }}$ mice; h) FVB ${ }^{\text {PAR-2-TgN }}$ mice after 7 months of CS exposure; i) air control WT mice; and j) WT mice after 7 months of CS exposure. Scale bars: $100 \mu \mathrm{m}$ in a-d; and $75 \mu \mathrm{m}$ in g-j. Immunohistochemical-based grading analysis for e) VEGF, and k) eNOS carried out on small arteries of lungs from air- or smoke-exposed mice for each experimental group at 2, 4 and 7 months of treatment. Data are presented as mean $\pm S D .{ }^{*}: p \leqslant 0.05$ compared with air-control small vessels of the same genotype at the same time point. Representative western blotting analysis with anti-VEGF antibody, and anti-eNOS and anti-phospho-eNOS antibodies are reported in f) and I), respectively. GAPDH: reduced glyceraldehyde phosphate dehydrogenase. 

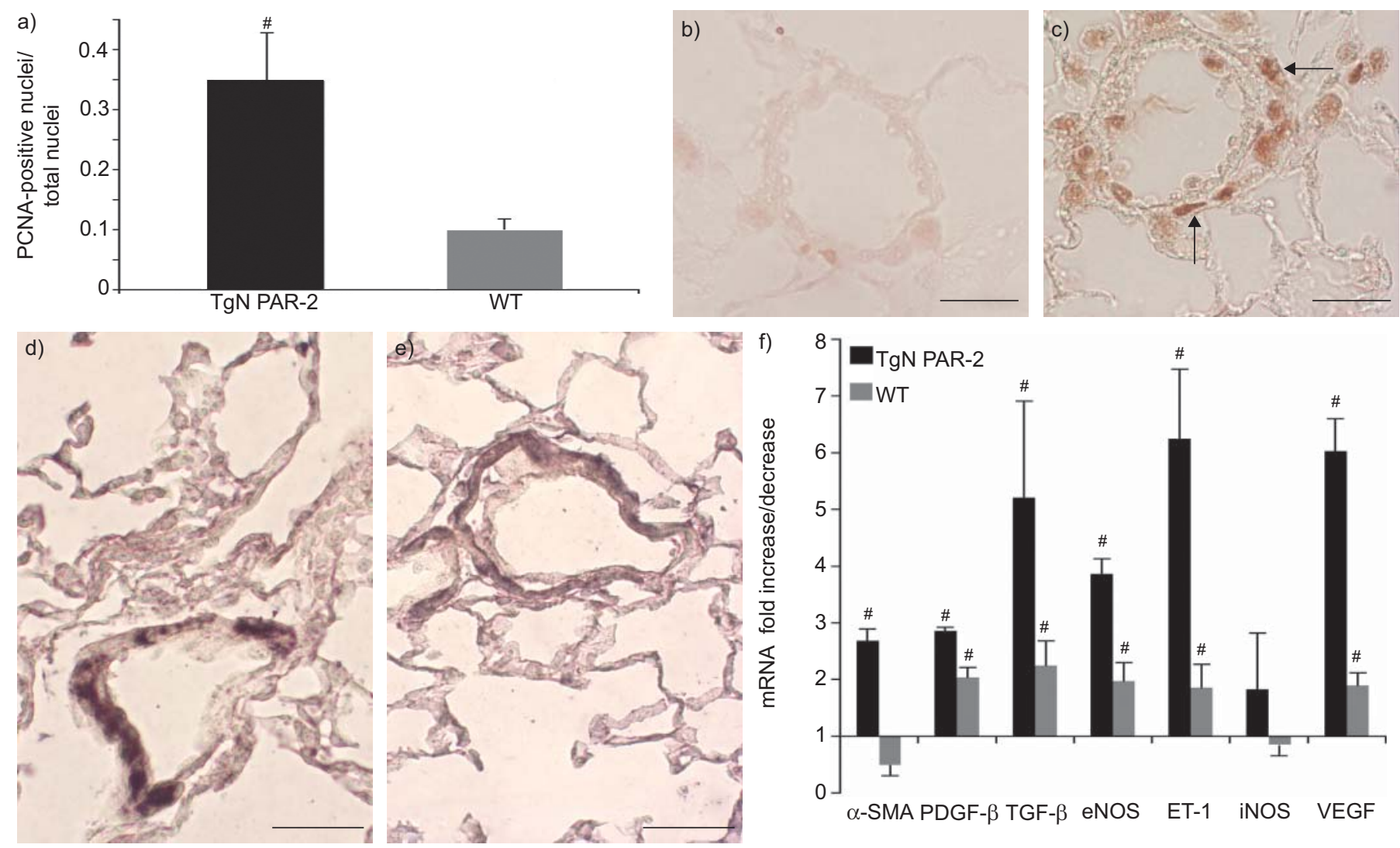

FIGURE 7. a) The ratio of proliferating cell nuclear antigen (PCNA)-positive nuclei to total nuclei of smooth muscle cells was compared between the two genotypes at 1 month after cigarette exposure. Smoking FVB PAR-2-TgN mice showed a significantly higher ratio of PCNA-positive smooth muscle cells $(p<0.01, n=8)$. Representative immunohistochemical reactions for PCNA in lung sections of b) wildtype (WT) and C) FVB PAR-2-TgN mice at 1 month after cigarette smoke (CS) exposure are shown Representative immunohistochemical reaction for PAR2 in small pulmonary vessels of d) FVB PAR-2-TgN and e) WT mice. Scale bars: $30 \mu \mathrm{m}$ in b and c; and $50 \mu \mathrm{m}$ for $d$ and e. f) Real-time PCR analysis of mRNAs for $\alpha$-smooth muscle actin (SMA), platelet-derived growth factor (PDGF)- $\beta$, transforming growth factor (TGF)- $\beta$, endothelial nitric oxide synthase (eNOS), endothelin (ET)-1, inducible nitric oxide synthase (iNOS) and vascular endothelial growth factor (VEGF) carried out on lungs from eight mice for each experimental group at 1 month after CS exposure. Values are corrected for 18S rRNA and normalised to a median control value of 1.0. Data are presented as mean \pm SD. \#: $p<0.05$ compared with air-control values of the same genotype.

of hypoxic response. This factor usually accumulates under hypoxic conditions and transactivates a number of genes, including ET-1, VEGF and PDGF, which have been involved in $\mathrm{PH}$ [32-34]. Under our experimental conditions, a positive reaction for HIF1- $\alpha$ was appreciated in FVB ${ }^{\text {PAR-2-TgN }}$ mice only at 7 months after CS exposure, when vascular changes were already evident.

Comparative analysis of data between $\mathrm{WT}$ and $\mathrm{FVB}^{\mathrm{PAR}-2-\mathrm{TgN}}$ mice exposed to CS suggests that TGF- $\beta$ and PDGF are involved, through PAR-2 signalling, in lung vascular muscularisation. The presence of TGF- $\beta$ in pulmonary vessels may enhance the expression of ET-1 that in turn can promote smooth muscle cell activation and vessel contraction.

These conclusions are in agreement with recent studies carried out under in vitro conditions that support an involvement of PAR-2 signalling in: 1) fibroblast recruitment and proliferation (through PDGF, TGF- $\alpha$ and MMP9 upregulation, and TGF- $\beta$ activation by MMP9) [35-37], 2) fibroblast/SMC transaction (through PDGF and TGF- $\beta$ hyper-expression and activation) $[27,28]$, 3) SMC proliferation (through PDGF) $[35,36]$ and 4) SMC activation and vessel contraction (through TGF- $\beta$ upregulated ET-1) $[38,39]$.

In conclusion, the combination of CS exposure with overexpression of PAR-2 gene in FVB mice results in emphysema and vascular remodelling associated with $\mathrm{PH}$ and $\mathrm{RVH}$. These changes are reminiscent of those characterising human COPD phenotypes with PH [20, 21]. Under our experimental conditions, PAR-2 signalling is able to influence the production and the release of many factors, which ultimately may lead to vascular remodelling and aberrant vascular physiology.

One established complication of COPD, a leading cause of morbidity and mortality worldwide [1-2], is the development of pulmonary hypertension $(\mathrm{PH})$. Its presence is associated with shorter survival rates and worse clinical evolution [4]. PH in COPD tends to be of moderate severity and progresses slowly [40-42]. At the present time, there is no specific and effective treatment for this condition and current therapeutic success is unsatisfactory because of limited insight into disease mechanisms [43]. 
Several pathophysiological processes have been involved in the pathogenesis of $\mathrm{PH}$ in COPD, namely: a) an increase in vascular pulmonary resistance due to capillary loss (alveolar destruction), b) pulmonary arterial vasoconstriction secondary to alveolar hypoxia, and c) vascular remodelling and proliferation of SMC in pulmonary arterioles that are normally non-muscular [44, 45].

A number of stimuli and putative mediators in the induction of $\mathrm{PH}$ in COPD have also been considered [22-24]. These include hormones, growth factors, neurotransmitters, proteases and environmental stresses that induce pulmonary vascular constriction, cell proliferation and remodelling [24, 25].

Actually, the presence of PH in COPD is still an object of research. One of the major impediments for understanding the underlying pathogenic mechanisms for $\mathrm{PH}$ in COPD is limited access to biological samples, which are available only from lung explants and autopsy specimens at very late stage of disease.

Recent studies indicate that CS may have, at least in some individuals, a direct effect on the intrapulmonary vessels with up-regulation of mediators that lead to vascular structural remodelling and dynamic changes in vascular function [46, 47]. A role for proteases in $\mathrm{PH}$ has been recently put forward $[46,48]$.

The results reported here may explain why hypoxia by itself is not a prerequisite to cause PH in COPD patients [46, 49] and why the development of $\mathrm{PH}$ in human COPD is not related to the degree of alveolar destruction [43].

In this regard, a correlation between development of $\mathrm{PH}$ and degree of emphysema is not found under our experimental conditions. In fact, CS exposure induces in WT mice a degree of airspace enlargement similar to that observed in overexpressing PAR-2 mice with $\mathrm{PH}$. The development of $\mathrm{PH}$, in our study, may be related to high levels of expression of PAR-2 in transgenic mice.

Assuming that the mouse data are relevant to humans, the results of the present study indicate that an increased expression of PAR-2 in a milieu rich in proteases (such as the lungs of COPD patients) [50] would influence the development of $\mathrm{PH}$. A number of serine proteases have been identified in the lung traditionally associated with COPD and PAR-2 is a target of several of these proteases, which include neutrophil elastase, cathepsin G, trypsin, mast cell tryptase and blood coagulation proteases $[8,50,51]$. Additonally, as reported in this paper and in human studies [52], cigarette smoke exposure may enhance expression of PAR2 in pulmonary structures.

The animal model reported in the current paper may represent a valuable resource by which to further our understanding of the biology of $\mathrm{PH}$, and to facilitate designing and testing of new therapeutic interventions in man. In our opinion, the individual susceptibility to $\mathrm{PH}$ in human COPD may be influenced by several important genetic determinants such as the different levels of expression in PAR-2 gene and the different inflammatory response to the tobacco smoke. This may explain why, under our experimental conditions, vascular remodelling did occur in the wild-type FVB mice, but not at the same extent to that observed in FVB ${ }^{\text {PAR-2-TgN }}$ mice.

\section{SUPPORT STATEMENT}

This work was supported by grants from MIUR, Rome, Italy (PRIN: prot. 2008T5BLWA) and the University of Siena, Italy (PAR grant 2006).

\section{STATEMENT OF INTEREST}

None declared.

\section{REFERENCES}

1 Celli BR, MacNee W. Standards for the diagnosis and treatment of patients with COPD: a summary of the ATS/ERS position paper. Eur Respir J 2004; 23: 932-946.

2 Mannino DM, Buist AS. Global burden of COPD: risk factors, prevalence, and future trends. Lancet 2007; 370: 765-773.

3 Mahadeva R, Shapiro SD. Chronic obstructive pulmonary disease * 3: Experimental animal models of pulmonary emphysema. Thorax 2002; 57: 908-914.

4 Oswald-Mammosser M, Weitzenblum E, Quoix E, et al. Prognostic factors in COPD patients receiving long-term oxygen therapy. Importance of pulmonary artery pressure. Chest 1995; 107: 1193-1198.

5 Yoshida T, Tuder RM. Pathobiology of cigarette smoke-induced chronic obstructive pulmonary disease. Physiol Rev 2007; 87: 1047-1082.

6 Ossovskaya VS, Bunnet NW. Protease-activated receptors: Contribution to physiology and disease. Physiol Rev 2004; 84: 579-621.

7 Hirano K, Kainade H. Role of protease-activated receptors in the vascular system. J Atheroscler Thromb 2003; 10: 211-225.

8 Chignard M, Pidard D. Neutrophil and pathogen proteinases versus proteinase-activated receptor-2 lung epithelial cells: more terminators than activators. Am J Respir Cell Mol Biol 2006; 34: 394-398.

9 Hirano K. The roles of proteinase-activated receptors in the vascular physiology and pathophysiology. Arterioscler Thromb Vasc Biol 2007; 27: 27-36.

10 Coughlin SR. Protease-activated receptors in haemostasis, thrombosis and vascular biology. J Thromb Haemost 2005; 3: 1800-1814.

11 Peters T, Henry PJ. Protease-activated receptors and prostaglandins in inflammatory lung disease. Br J Pharmacol 2009; 158: 1017-1033.

12 Churg A, Cosio M, Wright JL. Mechanisms of cigarette smokeinduced COPD: insights from animal models. Am J Physiol Lung Cell Mol Physiol 2008; 294: L612-L631.

13 Martorana PA, Cavarra E, Lucattelli M, et al. Models for COPD involving sigarette smoke. Drug Discovery Today 2006; 3: 225-230.

14 Brusselle GG, Bracke KR, Maes T, et al. Murine models of COPD. Pulm Pharmacol Ther 2006; 19: 155-165.

15 Schmidlin F, Amadesi S, Dabbagh K, et al. Protease-activated receptor 2 mediates eosinophil infiltration and hyperreactivity in allergic inflammation of the airway. J Immunol 2002; 169: 5315-5321.

16 Cavarra E, Bartalesi B, Lucattelli M, et al. Effects of cigarette smoke in mice with different levels of alpha1-proteinase inhibitor and sensitivity to oxidants. Am J Respir Crit Care Med 2001; 164: 886-890.

17 Schultz K, Fanburg BL, Beasley D. Hypoxia and hypoxia-inducible factor- $1 \alpha$ promote growth factor-induced proliferation of human vascular smooth muscle cells. Am J Physiol Heart Circ Physiol 2006; 290: H2528-H2534.

18 Stenmark KR, Fagan KA, Frid MG. Hypoxia-induced pulmonary vascular remodeling: cellular and molecular mechanisms. Circ Res 2006; 99: 675-691.

19 Fulton D, Gratton JP, McCabe TJ, et al. Regulation of endotheliumderived nitric oxide production by the protein kinase Akt. Nature 1999; 399: 597-601.

20 Wilkinson $\mathrm{M}$, Langhorne CA, Heath D, et al. A pathophysiological study of 10 cases of hypoxic cor pulmonale. Q J Med 1988; 66: 65-85. 
21 Magee F, Wright JL, Wiggs BR, et al. Pulmonary vascular structure and function in chronic obstructive pulmonary disease. Thorax 1988; 43: 183-189.

22 Humbert M, Morrell NW, Archer SL, et al. Cellular and molecular pathobiology of pulmonary arterial hypertension. J Am Coll Cardiol, 2004; 43: Suppl. 12, S13-S24.

23 Voelkel NF, Tuder RM. Cellular and molecular mechanisms in the pathogenesis of severe pulmonary hypertension. Eur Respir J 1995; 8: 2129-2138.

24 Strange JW, Wharton J, Phillips PG, et al. Recent insights into the pathogenesis and therapeutics of pulmonary hypertension. Clin Sci 2002; 102: 253-268.

25 Stenmark KR, Davie N, Frid M, et al. Role of the adventitia in pulmonary vascular remodeling. Physiology 2006; 21: 134-145.

26 Said SI. Mediators and modulators of pulmonary arterial hypertension. Am J Physiol Lung Cell Mol Physiol 2006; 291: L547-L558.

27 Jones R, Capen D, Jacobson M. PDGF and microvessels wall remodelling in adult lung: imaging PDGF-R $\beta$ and PDGF-BB molecules in progenitor smooth muscle cells developing in pulmonary hypertension. Ultrastruct Pathol 2006; 30: 267-281.

28 Gao PJ, Li Y, Sun AJ, et al. Differentiation of vascular myofibroblasts induced by transforming growth factor- $\beta 1$ requires the involvement of protein kinase C- $\alpha$. J Mol Cell Cardiol 2003; 35: 1105-1112.

29 Pan D, Yang J, Lu F, et al. Platelet-derived growth factor BB modulates PCNA protein synthesis partially through the transforming growth factor $\beta$ signalling pathway in vascular smooth muscle cells. Biochem Cell Biol 2007; 85: 606-615.

30 Schermuly RT, Dony E, Ghofrani HA, et al. Reversal of experimental pulmonary hypertension by PDGF inhibition. J Clin Invest $2005 ; 115 ; 2811-2821$.

31 Hirano K, Kanaide H. Role of protease-activated receptors in vascular system. J Atheroscler Thromb 2003; 10: 211-225.

32 Semenza GL. Perspectives on oxygen sensing. Cell 1999; 98: 281-284.

33 Jiang BH, Zheng JZ, Leung SW, et al. Transactivation and inhibitory domains of hypoxia-inducible factor $1 \alpha$. Modulation of transcriptional activity by oxygen tension. J Biol Chem 1997; 272: 19253-19260.

34 Semenza GL. Hypoxia-inducible factor 1: oxygen homeostasis and disease pathophysiology. Trends Mol Med 2001; 7: 345-350.

35 Siegbahn A, Johnell M, Nordin A, et al. TF/FVIIa transactivate PDGFR $\beta$ to regulate PDGF-BB-induced chemotaxis in different cell types: involvement of Src and PLC. Arterioscler Thromb Vasc Biol 2008; 28: 135-141.
36 Kouri FM, Eickelberg O. Transforming growth factor- $\alpha$, a novel mediator of strain-induced vascular remodeling. Circ Res 2006; 99: 348-350.

$37 \mathrm{Yu}$ Q, Stamenkovic I. Cell surface-localized matrix metalloproteinase-9 proteolytically activates TGF- $\beta$ and promotes tumor invasion and angiogenesis. Genes Dev 2000; 14: 163-176.

38 Perez-Zoghbi JF, Sanderson MJ. Endothelin-induced contraction of bronchiole and pulmonary arteriole smooth muscle cells is regulated by intracellular $\mathrm{Ca}^{2+}$ oscillations and $\mathrm{Ca}^{2+}$ sensitization. Am J Physiol Lung Cell Mol Physiol 2007; 293: L1000-L1011.

39 Rodrìguez-Pascual $\mathrm{F}$, Reimunde FM, Redondo-Horcajo $\mathrm{M}$, et al. Transforming growth factor-beta induces endothelin-1 expression through activation of the smad signalling pathway. J Cardiovasc Pharmacol 2004; 44: S39-S42.

40 Barberà JA, Peinado VI, Santos S. Pulmonary hypertension in chronic obstructive pulmonary disease. Eur Respir J 2003; 21: 892-905.

41 Weitzenblum E. Chronic cor pulmonale. Heart 2003; 89: 225-230.

42 Chaouat A, Bugnet AS, Kadaoui N, et al. Severe pulmonary hypertension and chronic obstructive pulmonary disease. Am J Respir Crit Care Med 2005; 172: 189-194.

43 Chaouat A, Naeije R, Weitzenblum E. Pulmonary hypertension in COPD. Eur Respir J 2008; 32: 1371-1385.

44 Presberg KW, Dincer HE. Pathophysiology of pulmonary hypertension due to lung disease. Curr Opin Pulm Med 2003; 9: 131-138.

45 Weitzenblum E, Schrijen F, Mohan-Kumar T, et al. Variability of the pulmonary vascular response to acute hypoxia in chronic bronchitis. Chest 1988; 94: 772-778.

46 Wright JL, Levy RD, Churg A. Pulmonary hypertension in chronic obstructive pulmonary disease: current theories of pathogenesis and their implications for treatment. Thorax 2005; 60: 605-609.

47 Wright JL, Tai H, Churg A. Vasoactive mediators and pulmonary hypertension after cigarette smoke exposure in the guinea pig. J Appl Physiol 2006; 100: 672-678.

48 Rabinovitch M. Pathobiology of pulmonary hypertension. Extracellular matrix. Clin Chest Med 2001; 22: 433-449.

49 Scharf SM, Iqbal M, Keller C, et al. Hemodynamic characterization of patients with severe emphysema. Am J Respir Crit Care Med 2002; 166: 314-322.

50 Taggart CC, Greene CM, Carroll TP, et al. Elastolytic Proteases: Inflammation Resolution and Dysregulation in Chronic Infective Lung Disease. Am J Respir Crit Care Med 2005; 171: 1070-1076.

51 Vesey DA, Hooper JD, Gobe GC, et al. Potential physiological and pathophysiological roles for protease-activated receptor- 2 in the kidney. Nephrology 2007; 12: 36-43.

52 Kwapiszewska G, Marsh LM, Markart P, et al. Potential role of protease-activated receptor-2 in pathogenesis of pulmonary hypertension. Am J Respir Crit Care Med 2009; 179: A1862. 